\title{
7. GEOPHYSICAL SURVEYS FOR LEG 59 SITES, DEEP SEA DRILLING PROJECT
}

\author{
Marcus G. Langseth and Cary L. Mrozowski, Lamont-Doherty Geological Observatory, \\ Columbia University, Palisades, N.Y.
}

During Legs 59 and 60, a transect of holes was drilled across the eastern part of the Philippine Sea at $18^{\circ} \mathrm{N}$. The sites included all of the major physiographic features along the transect.

This report describes the results of geophysical surveys carried out by Lamont-Doherty Geological Observatory's (L-DGO) research ships (the Vema and the Robert D. Conrad) in preparation for drilling on Leg 59 . The underway geophysical data collected at each site included $3.5-$ and $12-\mathrm{kHz}$ echo soundings, measurements of total-field magnetic intensity and acceleration due to gravity, single-channel seismic reflection profiles recorded by the Vema $(20 \mathrm{cu}$. in. air gun as sound source), and 24-channel digitally recorded reflection profiles collected by the Conrad (4-442 cu. in. air guns as sound source). In addition, seismic-refraction profiles, using sonobuoys, were made in most of the survey areas, and piston cores, dredges, and heat-flow measurements were attempted at some of the sites where the conditions were favorable.

The detailed surveys reported here were carried out on the Vema's Cruise 34, Leg 2 in April of 1977. The Conrad on Cruise 20, Leg 6, made a continuous multichannel seismic (MCS) traverse of the eastern Philippine Sea, which crossed the prospective sites for DSDP Legs 59 and 60 . Only the MCS results from crossings over the drill sites of Leg 59 are reported here.

\section{REGIONAL SETTING}

The South Philippine transect of IPOD-DSDP holes crosses the southeast quadrant of the Philippine Sea (Fig. 1). This region is thought to have evolved primarily by emplacement of the oceanic lithosphere behind the Mariana arc-trench complex that has migrated eastward relative to the Palau-Kyushu Ridge (Karig, 1971a). Two prominent aseismic ridges run roughly north-south through the area. These ridges are thought to be remnant arcs (Karig, 1972), i.e., portions of the Mariana Arc complex that have rifted away and remained behind as the complex migrates. These aseismic ridges, plus the Mariana Ridge, which is volcanically and seismically active, enclose two basins; the largest is the Parece Vela Basin, which lies between the PalauKyushu and West Mariana Ridges. Some bathymetric profiles across this basin are shown in Figure 2. It can be seen that the basin is divided into eastern and western provinces by a zone of very high relief at about $139^{\circ}$ $40^{\prime} \mathrm{E}$. The western half is characterized by rough topography, whereas the eastern region is much smoother. The central zone of rough topography, which includes several extraordinary deeps, has been named the Parece
Vela Rift and may be an extinct spreading axis (Mrozowski and Hayes, 1979). The Mariana Trough lies between the West Mariana Ridge and the Mariana Ridge and appears to have an actively spreading rift zone running along its central axis (Karig, 1971a; Anderson, 1975; and Karig et al., 1978). Thus new lithosphere is being added to the Philippine Plate in this basin as the Mariana Ridge migrates eastward relative to the West Mariana Ridge.

The average depth in the Mariana Trough is 3600 to 4000 meters and, in the Parece Vela Basin, 4800 to 5200 meters. The seismic observations in both basins show them to be floored by oceanic crust (Murauchi et al., 1968; Mrozowski and Hayes, 1979; La Traille and Hussong, in press). The West Philippine Basin is to the west of the Palau-Kyushu Ridge. This basin is deep (5500$6000 \mathrm{~m}$ ) and is topographically smoother than is the western Parece Vela Basin. Topographic trends and magnetic lineations trend approximately northwest and intersect the Palau-Kyushu Ridge at a large angle. A narrow zone of very rough topography, the Central Basin Ridge, also trends northwest and bisects the basin. This zone has been interpreted by some investigators as an extinct spreading center. It is likely that the West Philippine Basin has had a different evolution than basins east of the Palau-Kyushu Ridge. The drill site in the West Philippine Basin was planned to study this contrast.

\section{THE WEST MARIANA RIDGE: IPOD-DSDP SITE 451}

The geophysical site surveying carried out on the West Mariana Ridge was within the rectangle bounded by $17^{\circ} 30^{\prime}$ and $18^{\circ} 00^{\prime} \mathrm{N}$ and $142^{\circ} 40^{\prime}$ and $143^{\circ} 30^{\prime} \mathrm{E}$. (Fig. 3). The lines are primarily oriented east-west, crossing from the foot of the ridge in the Mariana Trough on the east, over the ridge complex, to the relatively smooth seafloor of the thick sedimentary apron lying on the western flank of the ridge (Karig, 1971b; Mrozowski and Hayes, 1979).

Bathymetry. At a large scale, the West Mariana Ridge appears to be a continuous and linear elevated massif; but at a local scale, the bathymetry is complex, as is shown by the contour map of the seafloor in the survey area (Fig. 3). Most of the east-west profiles (Fig. 2C) show that the ridge is bounded on the east by steep escarpments. Often, these precipitous slopes are broken by narrow terraces. The profiles of this eastern flank change considerably. For example, near $18^{\circ} \mathrm{N}$, there is a large hill or ridge that lies well east of the main ridge trend (Figs. 3 and 4). The topography of the eastern 


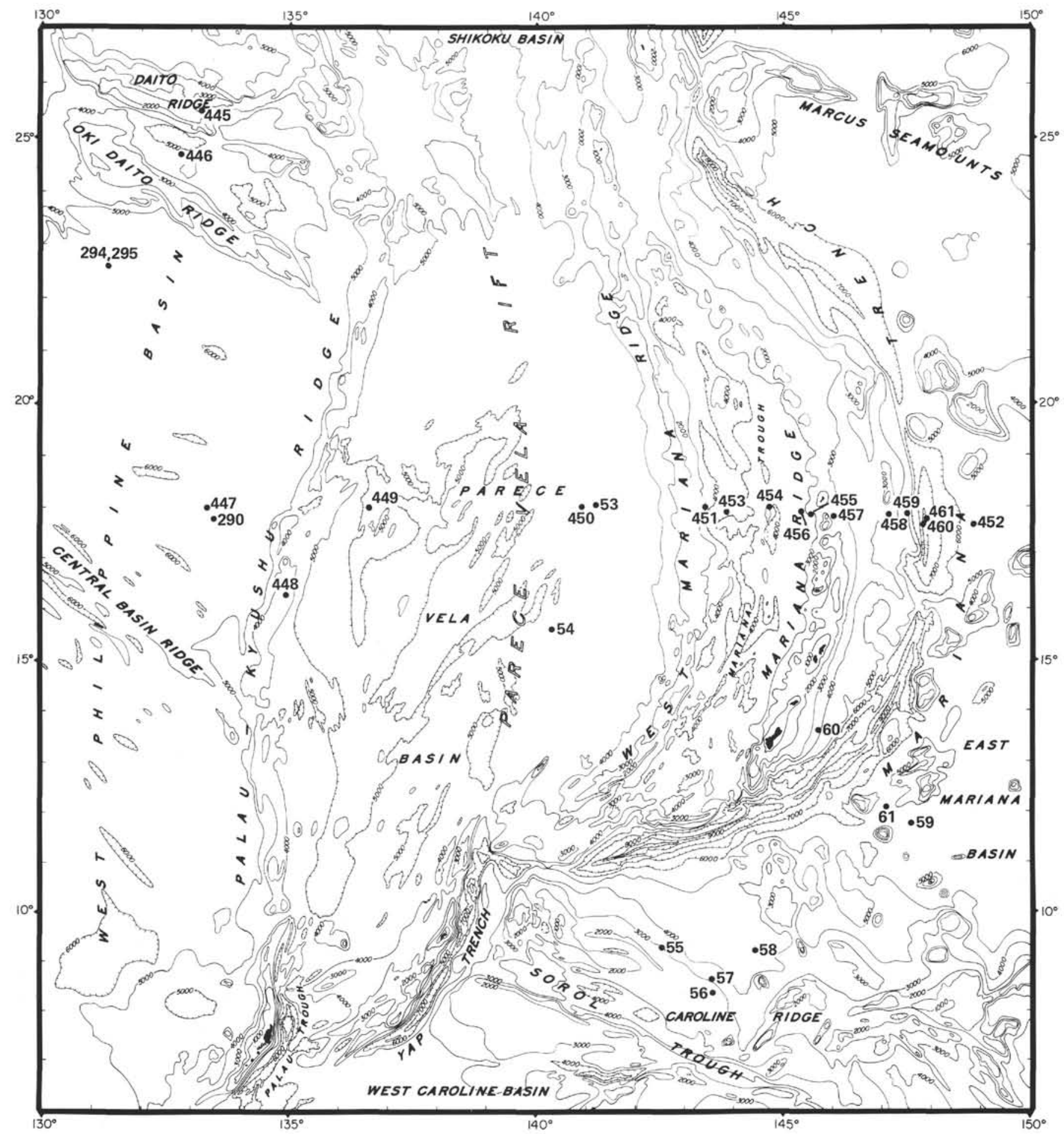

Figure 1. Bathymetry of the eastern part of the Philippine Sea, simplified from the map of Mammerickx et al., 1977. (Contours are in corrected meters. IPOD-DSDP sites are indicated by numbered black dots).

flank of the ridge appears to be an expression of massive normal faulting. Subsidence of terrain that once lay east of the ridge along the traces that run subparallel to the trend of the ridge seems to have occurred.

Within the survey area, the ridge is 60 to $80 \mathrm{~km}$ wide, and the profile changes profoundly along the short $50-\mathrm{km}$ segment surveyed. A broad trough about $20 \mathrm{~km}$ wide cuts diagonally across the ridge from the northwest to the southeast. This depression, which intersects all of the ridge trends, is no doubt structural; but, it is not clear how it is related to the tectonic development of the ridge.

One very large seamount complex rises to very shallow depths in the southwestern corner of the survey area. The minimum observed depth on this flat-topped bank is 73 meters below sea level. It is likely that it emerged as an island during the Pleistocene sea-level 

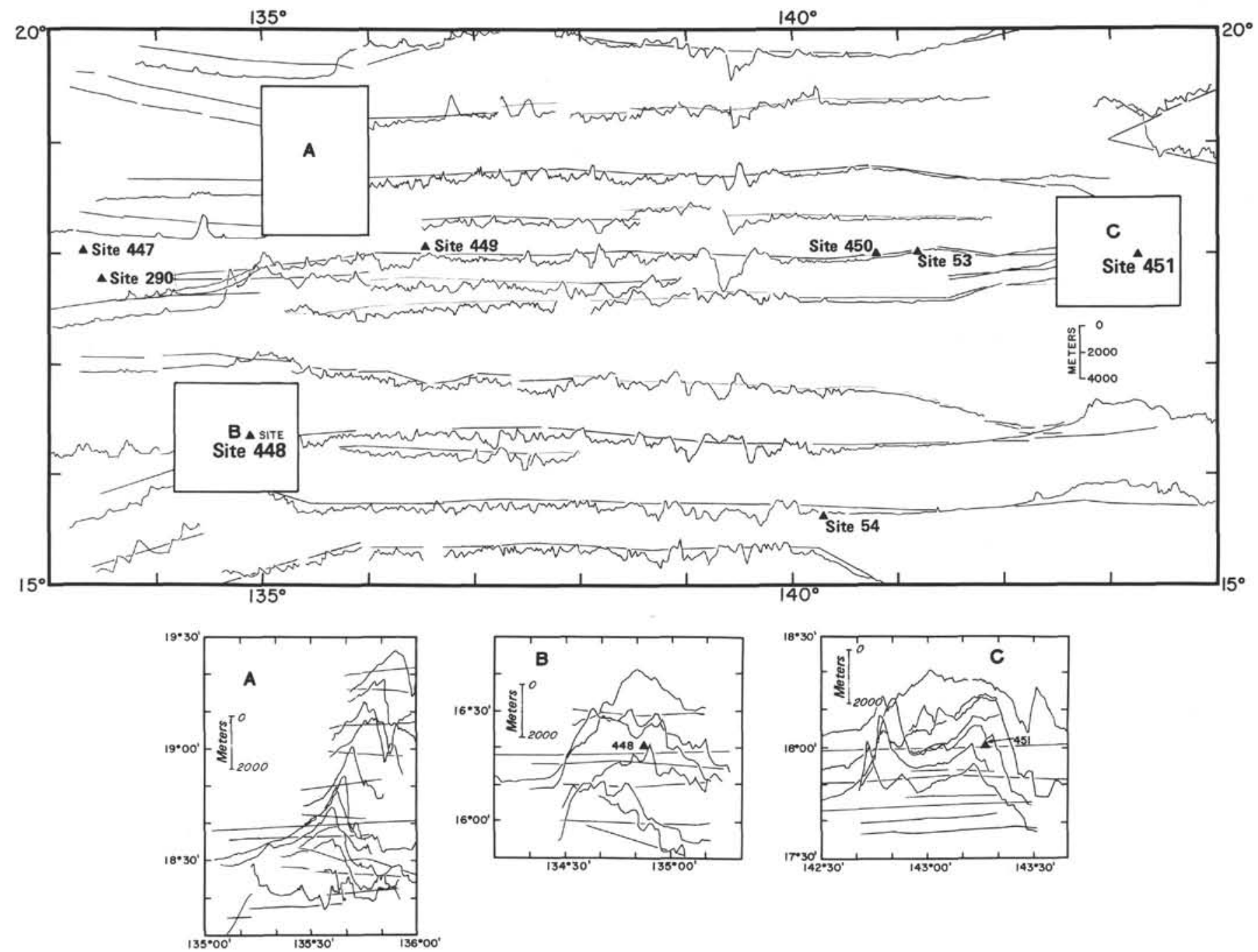

Figure 2. Bathymetric profiles along ship tracks. (Trackline equals $4500-\mathrm{m}$ depth. IPOD-DSDP sites are indicated by solid triangles. See fig. 2 in Mrozowski and Hayes [1979] for additional profiles.)

lowering. The numerous seamounts seen along the West Mariana Ridge are volcanic in origin and give evidence that the core of this ridge was probably built as a volcanic arc, similar to the Mariana Arc, which is volcanically active today.

Sediments. Except for the steep-sided seamount, the West Mariana Ridge in the survey area is draped by thick deposits of sediments. Along most of the track, the single-channel seismic-reflection system did not penetrate through to the acoustic basement. The sediments are acoustically opaque; but in many places, reflectors can be seen to a depth of half a second (approximately a half kilometer). On the MCS profile, Figure 4 , the sub-bottom acoustic stratigraphy is still poorly defined. Across the broad elevated ridge, on which Site 451 is located, a discontinuous band of more prominent reflections can be traced at 0.8 to $1.0 \mathrm{~s}$ subbottom. South of this profile, a sonobuoy refraction profile in the survey area indicates that this reflector may be the top of a $4.2-\mathrm{km} / \mathrm{s}$ layer.

Core samples from the 900 -meter deep hole drilled at Site 451 disclosed a 36-meter layer of Pliocene and younger foraminiferal oozes overlying a thick sequence of Miocene volcanic ash, tuffs, and breccias (Kroenke and Scott, 1978). Volcaniclastic sediments probably comprise the upper second of two-way travel time on the record of Figure 4. The seismic-reflection records show that the acoustic stratigraphy is quite discontinuous and deformed. Thus the drape of Miocene volcanic sediments appears to have been highly disrupted by tectonic processes of the ridge during and subsequently to deposition.

Sonobuoy Refraction. Two sonobuoy refraction profiles were run north-south along the crest of the West Mariana Ridge (Fig. 3). Only one of the profiles, Sonobuoy 1, yielded useful results (Table 1). We observed a refractor with a velocity of $4.2 \mathrm{~km} / \mathrm{s}$ at a calculated depth sub-bottom of $1.1 \mathrm{~km}$ and a deeper refractor that is $2.4 \mathrm{~km}$ sub-bottom with an apparent velocity of $5.05 \mathrm{~km} / \mathrm{s}$. These velocities are appropriate for the basement of a volcanic-arc complex comprised of indurated volcaniclastics and intermixed with effusive and intrusive bodies of lava; and, the velocities are in reasonable agreement with refraction results on other remnant arcs (e.g. the summary by Karig, 1972).

No direct measurement of the seismic velocity of the upper 1-km-thick layer was obtained from the sonobuoy refraction results. Wide-angle reflections were not 


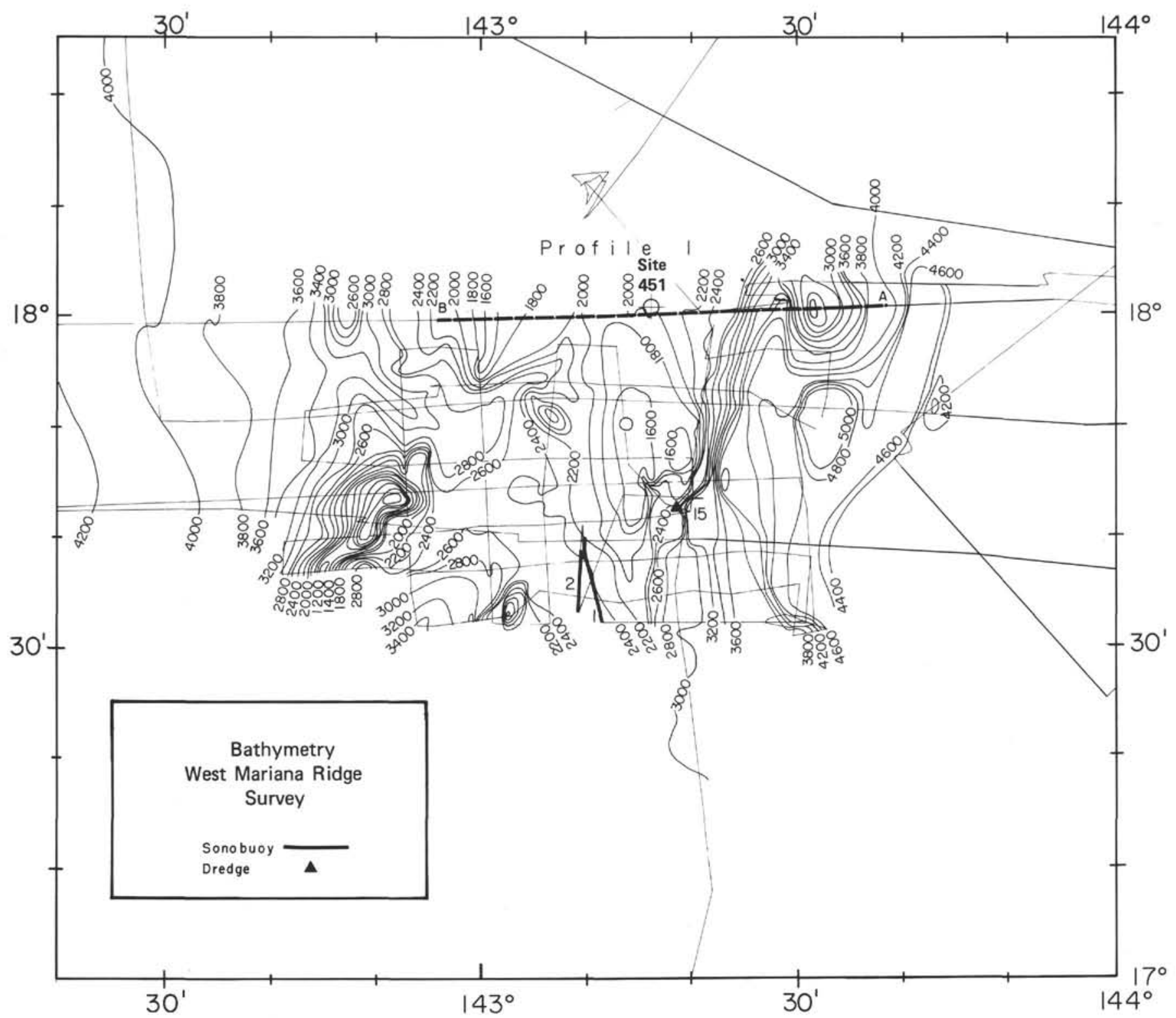

Figure 3. Bathymetric contour map of the West Mariana Ridge at IPOD-DSDP Site 451. (Contours are in corrected meters. Location of Profile 1

[Fig. 4] is shown by the heavy dashed line.)

clearly seen on the recording. Drilling results and the multichannel seismic profile (Fig. 4) suggest that this layer is composed of relatively unconsolidated sediments. As a consequence, we assumed a velocity of $2.0 \mathrm{~km} / \mathrm{s}$ for this layer in the reduction of the data. This velocity is consistent with interval velocities derived from the multichannel profile velocity data.

Dredge Samples. Two dredges were attempted on the steep eastern face of the West Mariana Ridge (Fig. 3). The deeper of the two attempts yielded no rocks, but the frame and net of the dredge were smeared with sediments. The second dredge on the slope between 2306 and 2873 meters yielded a suite of highly weathered mafic rocks. Most of the rocks were altered to a soft greenish yellow chalk. Many of the chunks were covered with a rind of manganese, and veins of manganite ran through the altered blocks. Pumice fragments were another prominent component of the dredge haul.
Summary. The results of the geophysical surveying on the West Mariana Ridge support the suggestion of Karig (1972) and others that it is an extinct volcanic arc. Volcanic activity on the ridge was probably continuous through most of the Miocene, when volcanic centers of the ridge were exposed as islands. The vast apron of sediments on the western flank of the ridge (Karig, 1975; Mrozowski and Hayes, 1979), accumulated during this time as ash from volcanoes and other debris, was transported westward by prevailing winds and currents. Much of the ridge remained submerged during this period, as evidenced by the 1-km layer of marine deposits draped over most of the survey area.

Until mid-Miocene, the West Mariana Ridge was joined with the present Mariana Arc, forming a much larger volcanic arc complex (Karig, 1971a). An active trench bounded the complex to the east, and a westward dipping Benioff Zone extended from the trench to 


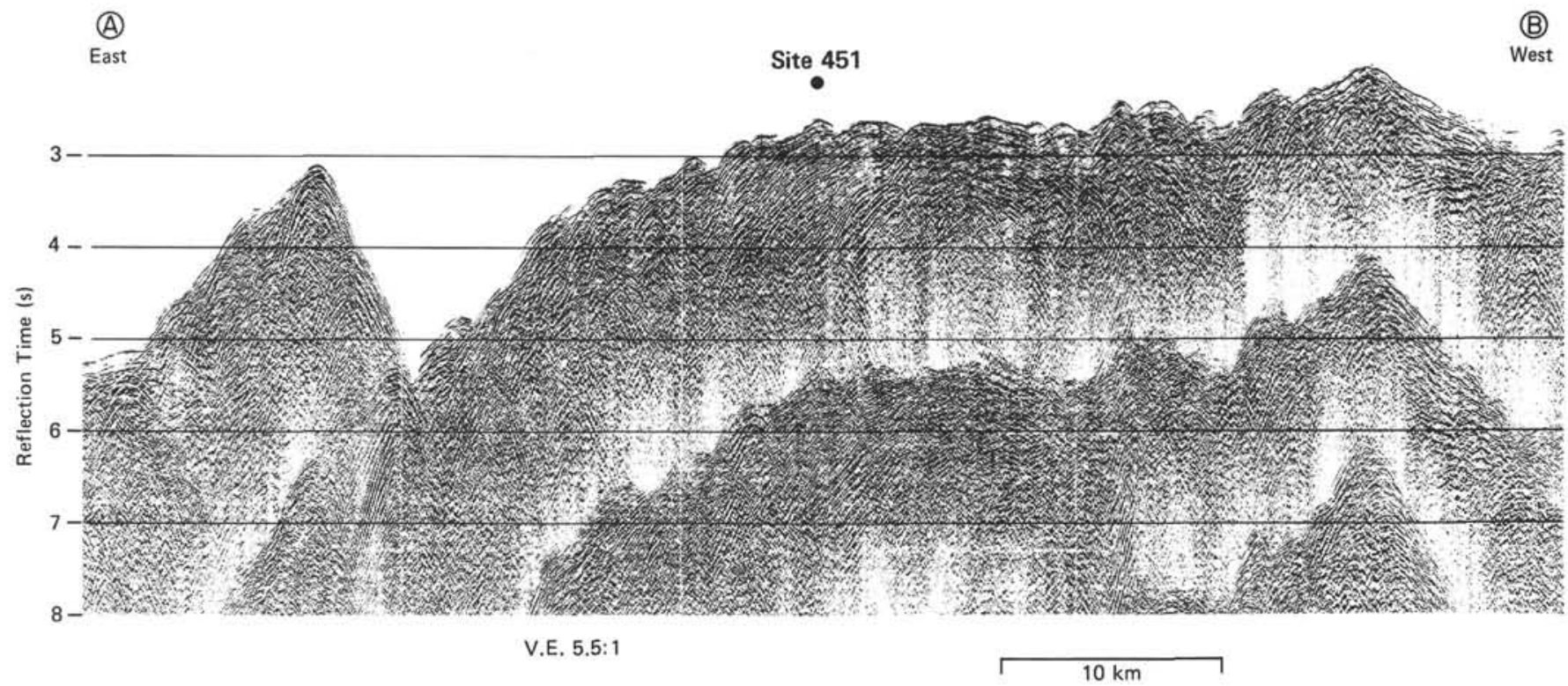

Figure 4. Profile 1: 24 -fold multichannel seismic profile across the West Mariana Ridge. (IPOD-DSDP Site 451 is indicated. Data was acquired during Cruise 20-06 of the Conrad. See Fig. 3 for the location of the profile.)

Table 1. Seismic-refraction data in the southeastern Philippine Sea.

\begin{tabular}{|c|c|c|c|c|c|c|c|c|c|c|c|c|}
\hline \multirow[b]{3}{*}{ Sonobuoy } & \multirow[b]{3}{*}{ Water } & \multirow{2}{*}{\multicolumn{4}{|c|}{$\begin{array}{c}\text { Thickness }(h), \\
(\mathrm{km})\end{array}$}} & \multirow{2}{*}{\multicolumn{5}{|c|}{$\begin{array}{c}\text { Velocity }(V) \\
(\mathrm{km} / \mathrm{s})\end{array}$}} & \multicolumn{2}{|c|}{ Location } \\
\hline & & & & & & & & & & & \multirow{2}{*}{$\begin{array}{l}\text { Latitude } \\
\text { (N) }\end{array}$} & \multirow{2}{*}{$\begin{array}{l}\text { Longitude } \\
\text { (E) }\end{array}$} \\
\hline & & $h_{2}$ & $h_{3}$ & $h_{4}$ & $h_{5}$ & $V_{2}$ & $V_{3}$ & $V_{4}$ & $V_{5}$ & $V_{6}$ & & \\
\hline V 34-01 & 2.4 & 1.08 & 1.33 & - & - & (2.0) & 4.2 & 5.05 & - & - & $17^{\circ} 33^{\prime}$ & $143^{\circ} 11.4^{\prime}$ \\
\hline V $34-03$ & 4.88 & 0.18 & 0.83 & - & - & (2.0) & 4.95 & 6.05 & - & - & $17^{\circ} 30^{\prime}$ & $140^{\circ} 00^{\prime}$ \\
\hline V 34-04 & 4.87 & 0.96 & - & - & - & (2.0) & 5.82 & - & - & - & $17^{\circ} 30^{\prime}$ & $140^{\circ} 06^{\prime}$ \\
\hline V 34-05 & 4.77 & 0.54 & - & - & - & 1.65 & 4.9 & - & - & - & $17^{\circ} 33^{\prime}$ & $140^{\circ} 52^{\prime}$ \\
\hline V 34-06 & 4.76 & 0.46 & 1.54 & - & - & 1.85 & 5.05 & 6.7 & - & - & $17^{\circ} 41.4^{\prime}$ & $140^{\circ} 52^{\prime}$ \\
\hline V 34-07 & 4.82 & 0.73 & 1.24 & - & - & (2.0) & 4.65 & 5.85 & - & - & $17^{\circ} 45^{\prime}$ & $140^{\circ} 04^{\prime}$ \\
\hline V $34-08$ & 4.81 & 0.92 & 1.04 & 0.73 & - & 2.38 & (4.5) & 5.75 & 6.45 & - & $17^{\circ} 30^{\prime}$ & $140^{\circ} 00^{\prime}$ \\
\hline V 34-09 & 4.77 & 0.73 & 1.18 & - & - & 1.97 & (4.5) & 6.0 & - & - & $17^{\circ} 46.8^{\prime}$ & $140^{\circ} 19.2^{\prime}$ \\
\hline V $34-15$ & 5.27 & 0.23 & 0.89 & - & - & $(2.0)$ & 4.5 & 6.80 & - & - & $17^{\circ} 52.2^{\prime}$ & $136^{\circ} 13.2^{\prime}$ \\
\hline V $34-16$ & 5.01 & 0.08 & 2.01 & - & - & (2.0) & 5.3 & 6.20 & - & - & $17^{\circ} 45^{\prime}$ & $136^{\circ} 13.8^{\prime}$ \\
\hline V $34-18$ & 5.93 & 0.20 & 1.51 & - & - & (2.0) & (5.4) & 7.0 & - & - & $18^{\circ} 30^{\prime}$ & $133^{\circ} 21^{\prime}$ \\
\hline C $20-191$ & 4.55 & 0.66 & - & - & - & (2.0) & 5.4 & - & - & - & $17^{\circ} 58.8^{\prime}$ & $140^{\circ} 12^{\prime}$ \\
\hline C $20-192$ & 4.31 & 0.23 & 0.74 & 1.98 & 2.15 & (2.0) & 3.0 & 4.16 & 4.94 & 7.7 & $17^{\circ} 59.0^{\prime}$ & $137^{\circ} 31.5^{\prime}$ \\
\hline C $20-193$ & 4.62 & 0.28 & 0.54 & - & - & (2.0) & 3.3 & 4.07 & - & - & $17^{\circ} 59.5^{\prime}$ & $137^{\circ} 03.5^{\prime}$ \\
\hline C 20-195 & 5.80 & 0.02 & 1.21 & 2.68 & - & (2.0) & 5.1 & 6.80 & 7.62 & - & $17^{\circ} 48.1^{\prime}$ & $133^{\circ} 50.1^{\prime}$ \\
\hline
\end{tabular}

below the arc and perhaps to the eastern margin of the Parece Vela Basin. The extinct volcanic peaks that now dot the western flank of the West Mariana Ridge mark the volcanic zone lying over this Miocene subduction zone.

In late Miocene, rifting began along a north-south line east of the then active volcanic zone. A major portion of the arc complex was split away to form the present Mariana Arc, leaving the western flank-the West Mariana Arc-as a remnant are (Karig, 1972). The Mariana Trough was formed within the rift as an interarc oceanic basin. The steep scarps that now bound the ridge on the east are probably fault planes along which normal faulting took place during the initial stages of rifting.

\section{PALAU-KYUSHU RIDGE: IPOD-DSDP SITE 448}

The geophysical survey was made between $16^{\circ}$ and $16^{\circ} 30^{\prime} \mathrm{N}$ and $134^{\circ} 20^{\prime}$ to $135^{\circ} 20^{\prime} \mathrm{E}$, which is south of the main transect line (Fig. 5). The detailed study was moved to this location, because some earlier tracks indicated that the segment of the Palau-Kyushu Ridge in the vicinity of $18^{\circ} \mathrm{N}$ has subdued topography (see the bathymetric profiles in Fig. 2) and therefore could be atypical. An earlier L-DGO track, Conrad 11-07, showed the ridge to be relatively broad and high at $16^{\circ} \mathrm{N}$. The surveying consisted of six new east-west tracks that crossed the ridge from flank to flank, spaced about $20 \mathrm{~km}$ apart. The main core of the ridge is about $60 \mathrm{~km}$ across.

Bathymetry. Generally, the Palau-Kyushu Ridge is deeper and narrower than the West Mariana Ridge. Minimum depths in the survey area are about 2900 meters, which is nearly 1400 meters deeper than the crest of the West Mariana Ridge. Like the West Mariana Ridge, the topographic profiles vary considerably along the ridge. Compare the profiles of Insets A and B in Figure 2: At $19^{\circ} \mathrm{N}$ (Inset A), the ridge is bounded by a steep 


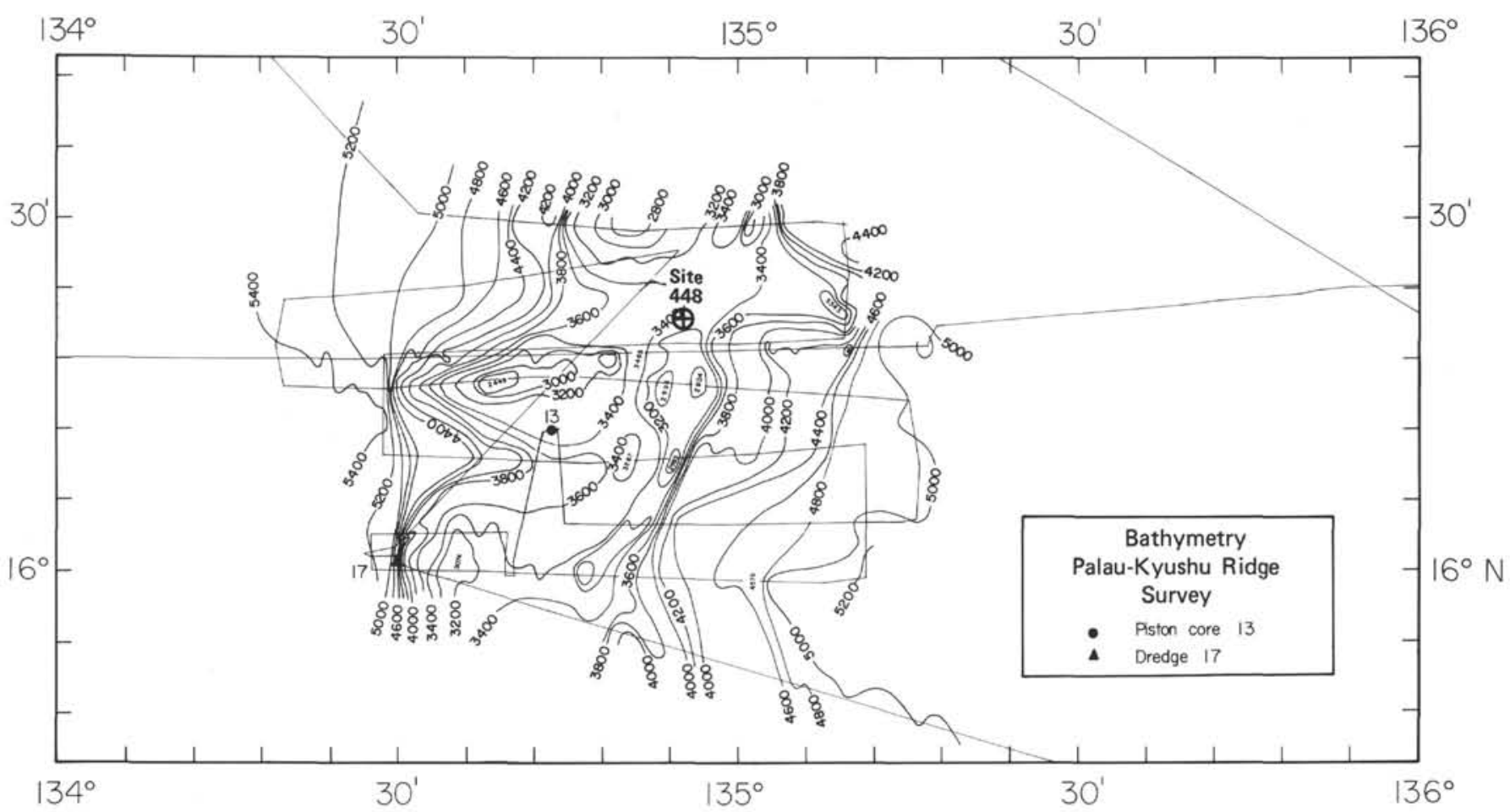

Figure 5. Bathymetric contour map of the survey area on the Palau-Kyushu Ridge. (The locations of piston core 13, dredge 17, and IPOD-DSDP Site 448 are shown. Contours are in corrected meters.)

eastward facing scarp, whereas in the IPOD Site Survey area (Inset B), the steepest scarps are facing westward.

Within the survey area, the western portion of the ridge is seen to be comprised of large mounds about 10 $\mathrm{km}$ across, rising to about 2900 meters. These are separated by troughs, one of which transects the entire ridge at $16^{\circ} 24^{\prime} \mathrm{N}$. The western flanks of these mounds exhibit very steep slopes. In contrast, slopes on the eastern flank of the ridge are relatively gentle. The asymmetry of this segment of the ridge, although not strongly developed, is the reverse of that of the West Mariana Ridge and the segment of the Palau-Kyushu Ridge at $19^{\circ} \mathrm{N}$ (D. E. Karig, personal communication). The steep western scarps may be formed by strike-slip faulting.

Site 448 was drilled to 2500 meters depth in a small saddle between two 2900 -meter peaks. The site is centrally located on the topography of the ridge.

Sediments. Much of the sediments detected by the single-channel reflection system are concentrated within small pockets formed between the numerous small ridges and peaks that decorate the ridge. There is a layer of acoustically transparent sediments 0.2 to $0.3 \mathrm{~s}$ thick covering these pockets and other areas of relatively flat terrain. These sediments are probably pelagic carbonates. Below the transparent layer, more reverberant layers were observed. These deposits, which are probably volcaniclastic debris, ashes, and tuffs, absorb most of the seismic energy so that deeper reflectors are obscured.

Results from Site 448 show that sediments more recent than the middle Miocene are missing. This may indicate that bottom currents through the intermontane troughs were sufficiently fast to prevent sedimentation during the Neogene. The transparent layer of sediments recently described may correspond to the upper-Oligocene and lower-Miocene carbonate chalks and oozes encountered in the upper 170 meters of the hole.

The multichannel seismic profile, made over the Palau-Kyushu Ridge at $18^{\circ} \mathrm{N}$, indicates a thick apron of sediments under the western flank of the ridge. In contrast, there is only a thin veneer of pelagic sediments covering oceanic basement adjacent to the eastern flank of the ridge. The apron of sediments is similar to that on the western flank of the West Mariana Ridge and probably has a similar origin (see Karig, 1971a). The ashes and turbidites that comprise the apron (Karig, Ingle, et al., 1975) were swept from the Palau-Kyushu Ridge when portions were emergent in the late Oligocene. At that time, the Palau-Kyushu Ridge was more massive and included components of the cores of the West Mariana Ridge and possibly even the Mariana Arc.

Dredge Results. A dredge was taken on the steep westward facing scarp in the southwestern corner of the survey area (Fig. 5). A single large boulder, dredged from an unknown depth on the scarp, consisted of agglomerated fragments of volcanic rocks. Most of the fragments were about hand-sized and were weathered vesicular basalt. One specimen was described more fully and was found to be a fine-grained basalt with randomly fine laths of plagioclase $(5 \%)$ and a few large orthopyroxenes that are euhedral to subhedral in crystal form (4\%); small augites (cpx) and olivines are not abundant, but are distributed randomly through the matrix. Vesicles comprise nearly $4 \%$ of the sample volume. A few of these vesicles are filled with smectite. Summary. The Palau-Kyushu Ridge is a remnant volcanic arc that was active during the late Oligocene. 
As was the case for the West Mariana Ridge, it represents only the western portion of what was no doubt a much larger arc complex. The eastern part has rifted away to form the West Mariana and Mariana Ridges. This scenario was proposed by Karig (1971a), and, by and large, the results of surveying support this evolution. The variable symmetry of the topographic profiles of the ridge, and especially the occurrence of steep faultgenerated scarps on the western side of the ridge, indicate that the tectonics of the ridge prior to the breakup were complex. Large strike-slip movement, paralleling the trends of the ridge, may have occurred.

After rifting, the remnant portion of the ridge began to subside. The total amount of subsidence is 3000 meters, if the ridge was at sea level at the time of the rifting. The Pacific floor has been subsiding at a rate well described by the simple relation:

$$
S=355(t)^{1 / 2} \quad \text { (Parsons and Sclater, 1977) }
$$

where $S$ is the amount of subsidence in meters and $t$ is the time elapsed since subsidence began in millions of years. For this expression, one can see that nearly 70 $\mathrm{m} . \mathrm{y}$. is required for the Pacific floor to subside 3000 meters. We know from the age of the oceanic crust east of the Palau-Kyushu Ridge (Mrozowski and Hayes, 1979) and the basal sediments drilled at Site 448 that rifting probably occurred 34 to 30 m.y. ago (Kroenke and Scott, 1978). Therefore the ridge either subsided at an abnormally high rate or it was considerably deeper when subsidence began. In our opinion, the first alternative is not a physically reasonable one. Thus it seems that the remnant ridge stood at a relatively great depth (about $1000 \mathrm{~m}$ ) after the rifting phase was complete. The initial subsidence may have been tectonically induced.

\section{THE EASTERN PARECE VELA BASIN: IPOD-DSDP SITE 450}

The region surveyed is located at the distal end of the sedimentary apron west of the West Mariana Ridge. Most of the tracks were made in the rectangle between $17^{\circ} 30^{\prime} \mathrm{N}$ and $18^{\circ} \mathrm{N}$ and $140^{\circ} \mathrm{E}$ and $141^{\circ} \mathrm{E}$ (Fig. 6). The area is nearly contiguous with, but southwest of, an area surveyed for DSDP Site 53 (Karig, 1971b).

Bathymetry. In the eastern part of the survey area, sedimentary deposits cover most of the basement peaks, so that the seafloor topography is subdued (Fig. 6). The bottom deepens gradually toward the west, reaching a regional maximum of about 4900 meters at $140^{\circ} 20^{\prime} \mathrm{W}$. Farther to the west, oceanic basement peaks begin to emerge; and westward of about $140^{\circ} \mathrm{E}$, the sediments form a thin pelagic layer covering basement topography. The seafloor rises toward the west as a series of high-relief $(700-800 \mathrm{~m})$ ridges and peaks.

In the eastern part of the survey area, where the sedimentary cover is relatively thick, there are several round bottom troughs about 50 to 150 meters deep that trend roughly north and south. The stratigraphy of the sediments below these troughs is generally conformable with the bottom contours. The troughs appear to be tectonically generated features, resulting from small displacement faulting in the basement subsequent to depo- sition of the sedimentary apron but prior to deposition of the pelagic drape that now covers the region (Karig, 1971b).

Sediments. The acoustical characteristics of the sedimentary cover in the area of this site have been described by Karig (1971b) at Site 53; 3.5-kHz records show a thin veneer of sediments 15 meters thick covering the entire region. This layer is rather uniform in thickness, except where the basement emerges, or in the rounded depressions where the layer thickens slightly. There are two prominent subsurface reflectors in flat regions: one at about 7 meters, probably corresponding to the base of a zeolitic clay unit cored at DSDP Site 53; and the second at 15 meters, probably corresponding to the silty radiolarian-ooze base-Unit B of Fischer, Heezen, et al. (1971). These units represent a pelagic drape over the whole region; if properly correlated with $3.5-\mathrm{kHz}$ reflecting horizons, they are thinner in the Site 450 survey area, compared with the Site 53 units. This suggests that laterally transported sediments from the east - probably windblown ashes and clays-made some contribution to this cover. The distribution of this sedimentary veneer indicates that its deposition postdates any tectonic movement that formed the troughlike depressions discussed earlier.

The single-channel seismic profiles show the sediment below the first 0.1-s two-way travel time to be highly stratified acoustically. Along most of the profiles, reflectors can only be discerned to a depth of 0.6 to $0.7 \mathrm{~s}$, and as a result the basement cannot be traced beneath the eastern part of the survey area. The acoustic stratigraphy over this region is no doubt associated with the Miocene tephras, which comprise a significant percentage of the apron sediments (see also the drilling results for Sites 53 and 450). The sedimentary and basement structure is clearly seen on the multichannel profile in Figure 7. The reflectors within the sediments are subparallel to the bottom, but they frequently onlap highs in the basement surface. This indicates that much of the sediments reached the area as bottom flows moving laterally from the east.

Other interesting features are the gentle folds seen in the acoustic stratigraphy. These are probably the result of small tectonic movements of the crust after most of the sedimentary layer had been deposited.

Magnetics. Magnetic anomalies in the survey area are of low amplitude. Maximum variations are on the order of 150 gammas. Nonetheless, the closely spaced tracks show north-south lineations tentatively identified as Anomalies 6 to $6 \mathrm{~B}$, indicating that this part of the floor has an age of about 19 to 23 m.y. (Mrozowski and Hayes, 1979).

Seismic-Refraction Studies. Eight sonobuoy refraction profiles were made in the survey area: seven were made during the Vema cruise and one on the Conrad cruise. Reduction of the travel-time data is based on planar layers with uniform velocity. The solutions are shown in Figure 8 and Table 1. On four of the profiles, the wideangle reflections from basement were discernible and allowed an estimate of the internal velocity in the sedimentary layer. The values range from 1.65 to 2.05 


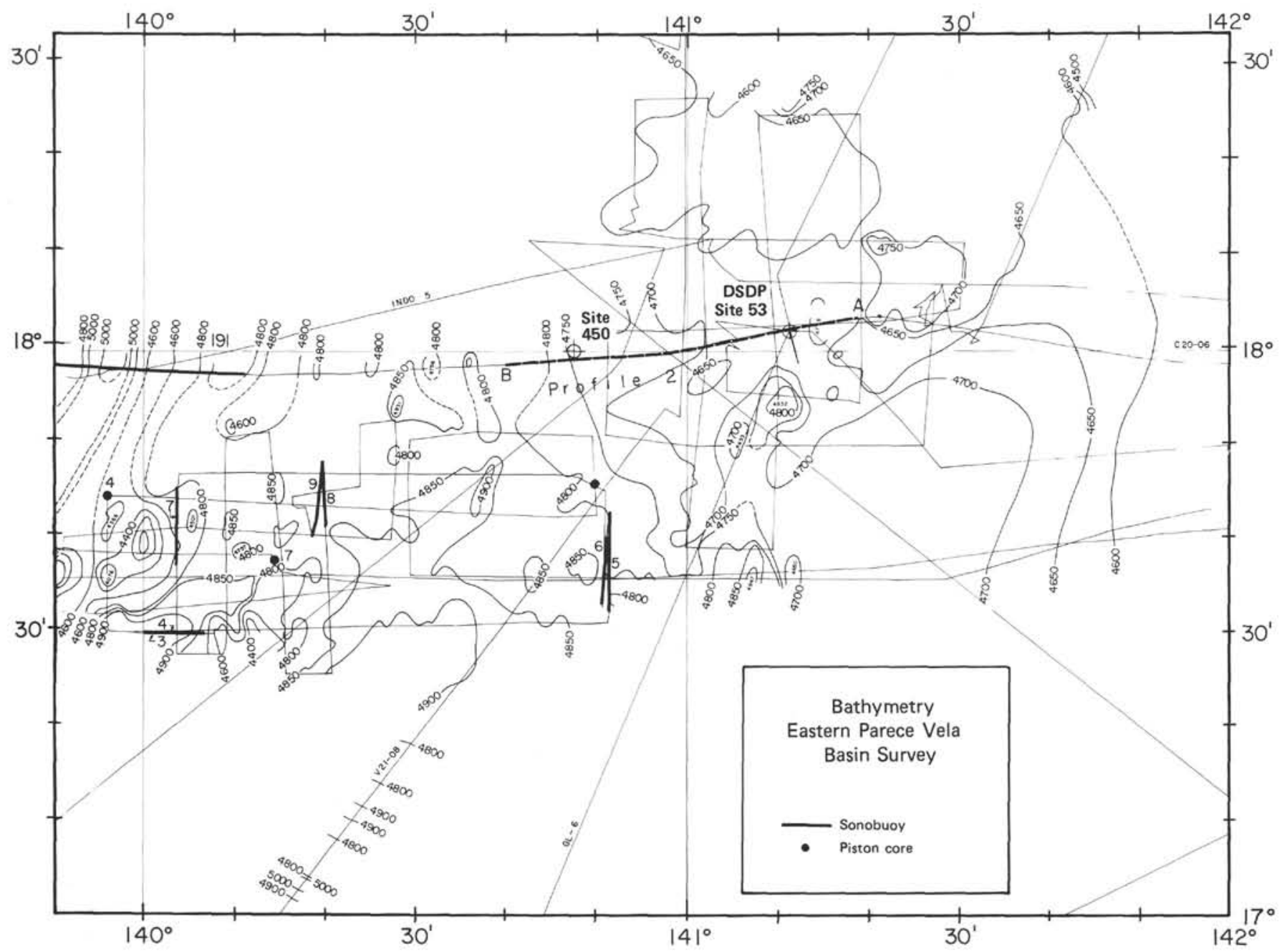

Figure 6. Bathymetric contour map of the survey of IPOD-DSDP Site 450, eastern Parece Vela Basin. (Bathymetric data from the SCAN IV survey [Karig, 1971b] have been included. Contours are in corrected meters. The location of sonobuoys [Fig. 8] and piston cores are shown; the position of Profile 2 [Fig. 7] is indicated by a heavy dashed line.)

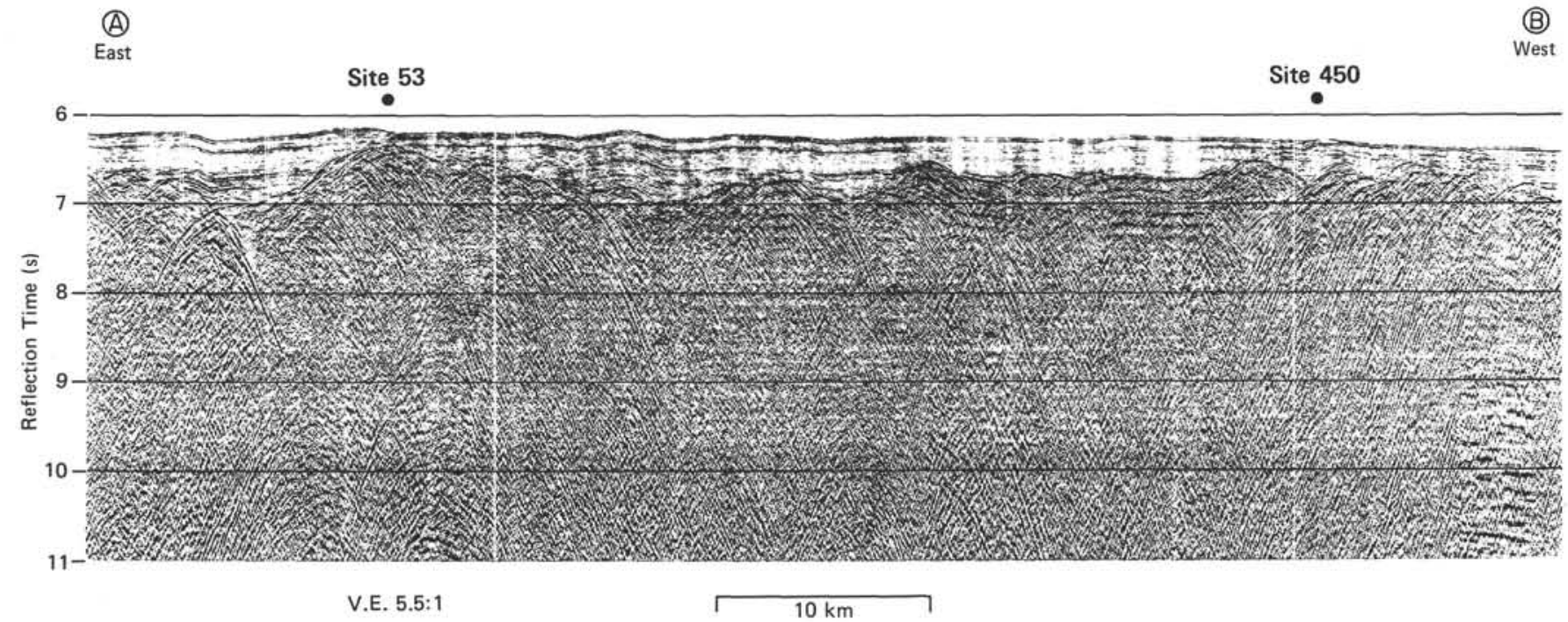

Figure 7. Profile 2: deconvolved 24-fold multichannel seismic profile across the distal portion of the sedimentary wedge, eastern Parece Vela Basin. (DSDP Site 53 [Leg 6] and IPOD-DSDP Site 450 are indicated. Data acquired during Cruise 20-06 of the Conrad. See Fig. 6 for the location of the profile.) 


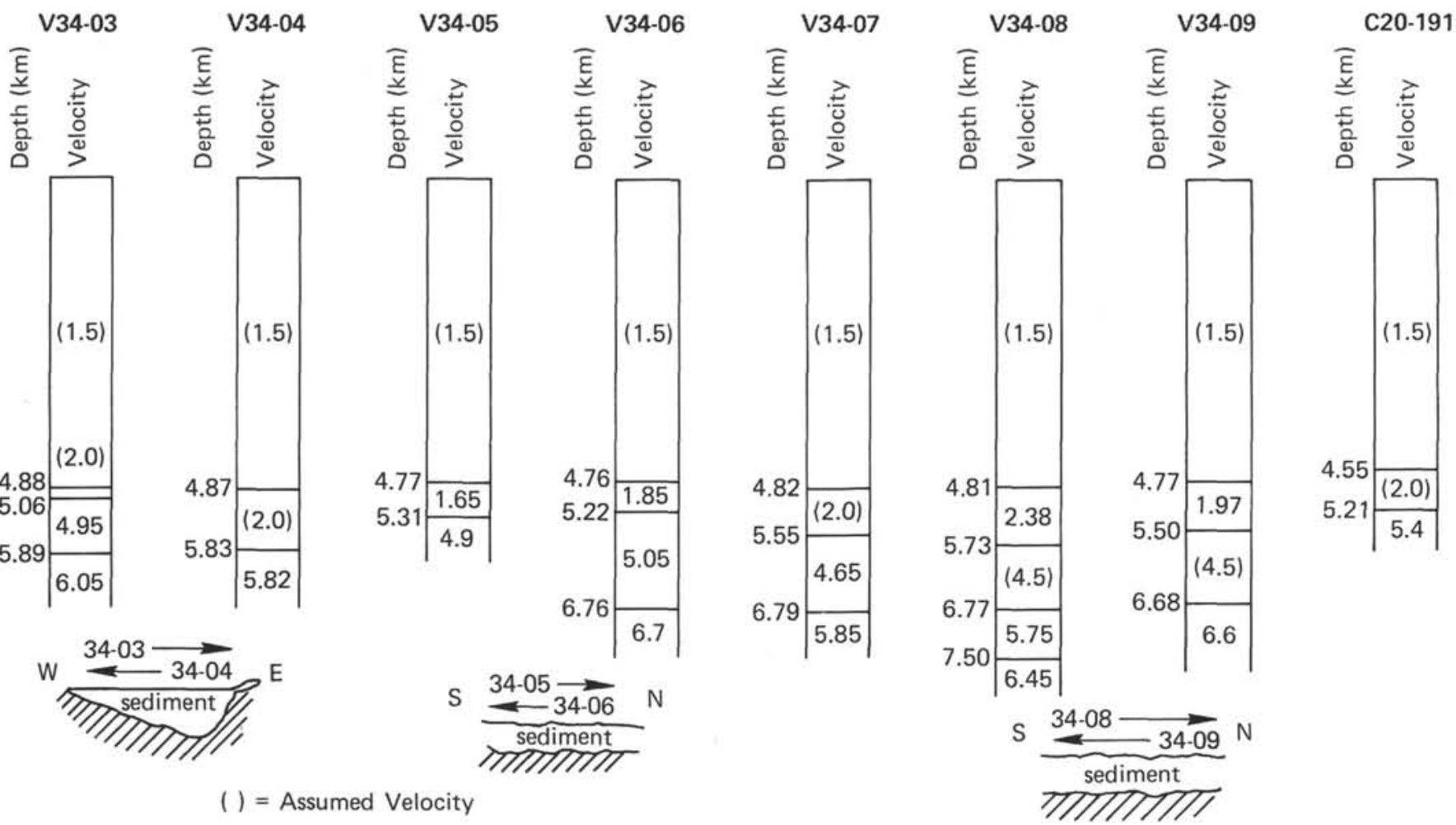

Figure 8. Solutions to sonobuoy refraction profiles in the eastern Parece Vela Basin survey area. (Planar uniform velocity layers were assumed for reduction of the travel-time data. For $P_{3}$ and $P_{4}$ an eastward-dipping basement surface was assumed. See Fig. 6 for sonobuoy locations.)

$\mathrm{km} / \mathrm{s}$. For those profiles where a direct measurement of the sedimentary velocity is not possible, an assumed value of $2.0 \mathrm{~km} / \mathrm{s}$ was used in the reduction. The sonobuoy results indicate an average velocity for the uppermost layer of $5.4 \mathrm{~km} / \mathrm{s}$, which is a typical value for Layer 2. Four of the profiles recorded arrivals from a deeper layer, probably corresponding to the top of Layer 3, with velocities ranging from 6.0 to $6.70 \mathrm{~km} / \mathrm{s}$. Much of the observed variation may be associated with topography on the Layer 2/Layer 3 interface. A twoship refraction profile, about $50 \mathrm{~km}$ east of the survey area (Murauchi et al., 1968), yielded a similar structure: a $1.5-\mathrm{km}$-thick Layer 2 with a velocity of $5.0 \mathrm{~km} / \mathrm{s}$ over a $6.8-\mathrm{km} / \mathrm{s}$-velocity Layer 3 . All refraction results indicate a normal oceanic crustal structure for Site 450 .

The results of this survey are summarized together with the results for the survey site in the western Parece Vela Basin at the end of the next section.

\section{THE WESTERN PARECE VELA BASIN: IPOD-DSDP SITE 449}

A drill site was chosen in the western half of the Parece Vela Basin primarily to test the age of the oceanic crust there, as well as to ascertain whether the lithosphere beneath the floor of the basin was formed at an axis of symmetric spreading (by comparison with Sites 450, 54, and 53); this information would help determine the time of initial rifting of the West Mariana Ridge from the Palau-Kyushu Ridge. Some seismic results indicate that an anomalously low-velocity layer caps the oceanic crust in the western part of the Parece Vela Basin. A region just east of the Palau-Kyushu
Ridge was chosen, and survey tracks were made in the rectangle enclosed by $17^{\circ} 30^{\prime} \mathrm{N}$ and $18^{\circ} 15^{\prime} \mathrm{N}$ and $136^{\circ} \mathrm{E}$ to $136^{\circ} 50^{\prime} \mathrm{E}$ (Fig. 9).

Bathymetry. Within the survey area, the bathymetry is largely shaped by elevated and depressed blocks of oceanic crust. These blocks are 20 to $40 \mathrm{~km}$ across. Site 449 is located on such an elevated block (Fig. 9). Typically, the elevated areas are at depths of 4500 to 4700 meters, whereas the deeper areas are commonly 5500 to 5800 meters. The multichannel profile in Fig. 10 shows a crossing from a raised block in the east (with a mean depth of $4700 \mathrm{~m}$ ) to a broad depressed area (with a depth of $5500 \mathrm{~m}$ ). In places, the elevated blocks are bounded by steep scarps that trend $040^{\circ}$ and $130^{\circ}$. These trends make angles of about $45^{\circ}$ with postulated spreading directions in the Parece Vela Basin.

Sediments. Sediments in the survey region are generally thin; in only two places do they exceed 350 meters. More typically, the sedimentary layer is less than 100 meters thick. We note that Hole 449 penetrated 111 meters of pelagic sediments. The thicker accumulations are found in the local deeps, and sediments are sparse to absent on the highs. The distribution can be seen clearly on the multichannel seismic profile.

An interesting result of the drilling was that the basal sediments were noncalcareous, suggesting that the crust was emplaced below the carbonate compensation depth (CCD) in the Oligocene.

Seismic-Refraction Studies. Seven sonobuoy refraction profiles were run, but five of these were in topography so rough that they cannot be reduced to give reliable layer velocities or thicknesses. Two of the profiles in the 


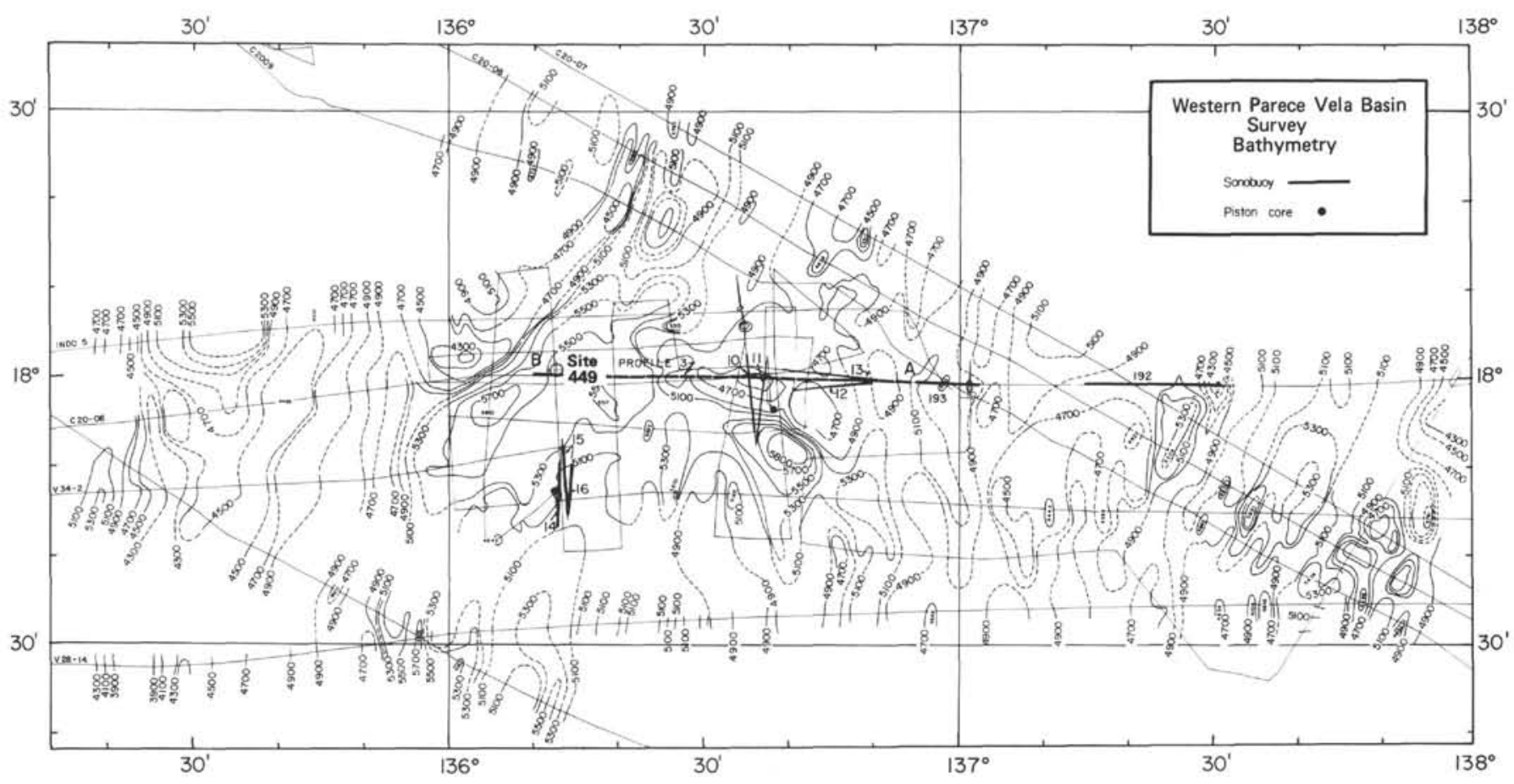

Figure 9. Bathymetric contour map of the survey area in the western Parece Vela Basin in the vicinity of IPOD-DSDP Site 449. (Contours are in corrected meters. Sonobuoy and piston-core stations are shown. Location of Profile 3 [Fig. 10] is shown by a heavy dashed line.)

(A)

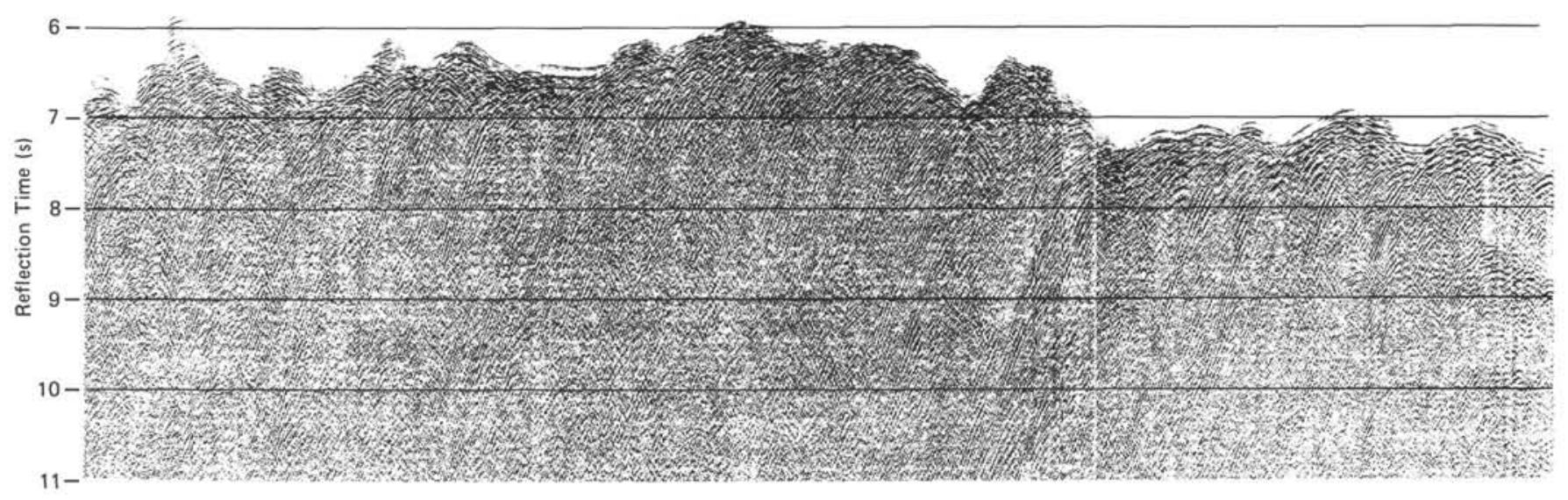

V.E. $5.5: 1$

$10 \mathrm{~km}$

Figure 10. Profile 3: 24-fold multichannel seismic profile across IPOD-DSDP Site 449 in the western Parece Vela Basin (Data was acquired during Cruise 20-06 of the Conrad. See Fig. 9 for the location of the profile.)

deeper southwestern part of the area, Sonobuoys 15 and 16 , gave reliable results (Table 1). Sonobuoy 15 indicates a relatively thin Layer 2 , about 900 meters, overlying a Layer 3 with a velocity of $6.8 \mathrm{~km} / \mathrm{s}$. Profile 16 , intended to be a reverse of Profile 15, yields a thicker Layer $2(2000 \mathrm{~m})$ with a velocity of $5.3 \mathrm{~km} / \mathrm{s}$ and a Layer-3 velocity of $6.2 \mathrm{~km} / \mathrm{s}$. These differing results may reflect a northward-dipping interface.

Magnetics. Despite the low-amplitude anomalies that characterize the entire Parece Vela Basin, a rather clear north-south lineation is defined by the east-west tracks in the survey area. Preliminary identification of the anomaly sequence suggests that the anomalies span from 28 to $25 \mathrm{~m} . \mathrm{y}$., that is, from late Oligocene to earliest Miocene.

Summary. The site survey results and re-examination of existing geophysical data defined a distinct pattern of magnetic anomalies that are symmetrical about the 
Parece Vela Rift and lineated north-south. The anomalies are low amplitude, and it is therefore difficult to be confident about a correlation with reversal chronology (e.g., Heirtzler et al., 1968; LaBrecque, et al., 1977), but a relatively good match can be demonstrated between anomalies in the western Parece Vela Basin and the Anomaly Sequence 10 to $5 \mathrm{E}$ or $5 \mathrm{D}$ (Mrozowski and Hayes, 1979). If valid, this suggests that the western Parece Vela Basin began forming about 31 m.y. ago (mid-Oligocene) and continued until at least $18 \mathrm{~m} . \mathrm{y}$. ago (the early Miocene). These reversal correlations match well with results at Site 449 (Kroenke and Scott, 1978). In the eastern part of the Parece Vela Basin, the drill hole apparently did not reach true basement, so that the symmetry and correlations there remain untested. The basalt sampled at the bottom of Hole 450 is thought to be an intersedimentary flow emplaced off axis.

A striking feature of the Parece Vela Basin is the roughness and complexity of the basement topography. The extinct Parece Vela Rift exhibits a highly variable profile along its length (see Appendix; Mrozowski and Hayes, 1979). Generally, the floors of the interarc basins of the eastern part of the Philippine Sea do not exhibit the subparallel and linear trends or the continuous and sharply defined fracture zones commonly seen on the flanks of mid-oceanic ridges, such as those of the eastern Pacific or the West Philippine Basin.

Lastly, we note that the mean depth for the area of 5000 meters is about 700 meters deeper than the depth predicted in the Pacific subsidence curve for crust 25 to 28 m.y. old (Kroenke and Scott, 1978; and Mrozowski and Hayes, 1979).

\section{THE WEST PHILIPPINE BASIN: IPOD-DSDP SITE 447}

Introduction. This site, centered at $18^{\circ} \mathrm{N}$ and $133^{\circ} \mathrm{E}$, is near the eastern margin of the West Philippine Basin (Fig. 11). It anchors the western end of the South Philippine Sea IPOD Transect. The basins of the eastern Philippine Sea can be linked by a nearly continuous tectonic history of the interarc basin formation beginning in the late Oligocene. However, the evolution of the West Philippine Basin appears from geophysical evidence to be very different and is still enigmatic. In contrast to Parece Vela Basin, the magnetic anomalies in the West Philippine Basin are well developed, and lineations trend about $15^{\circ} \mathrm{N}$ of west, making a $75^{\circ}$ angle with the main, structural trends of the eastern part of the Philippine Sea (see, for example, Watts et al., 1977; Louden, 1976). Topographic trends in the form of low-relief ridges and troughs are parallel to the magnetic lineations.

One interpretation of the magnetic evidence suggests that the lithosphere of the West Philippine Basin formed at the Central Basin Ridge and that this feature is an extinct spreading center (Louden, 1976; Watts et al., 1977). However, the data supporting this hypothesis are still not conclusive.

The site surveyed is about $275 \mathrm{~km}$ north-northeast of the Central Basin Ridge. The main tracks of the survey were run $15^{\circ}$ east of north and are roughly perpendicular to the Central Basin Ridge.
A major objective of the geophysical work at this site was detailed refraction profiling, using ocean-bottom seismometers. These experiments were carried out; however, the results are marginally useful because of the malfunction of two of the three instruments and of the problems of detonating large explosives regularly. Two of the four sonobuoy refraction profiles in the area gave reliable results. Earlier results (Murauchi et al., 1968) suggest that Layer 2 may be abnormally thin in this area. Bathymetry. Compared to sites in the eastern Philippine Sea, the topography within the survey area is subdued-about 200 meters of relief is typical (Fig. 11). The average depth is nearly 6000 meters, which is similar to that of the Mesozoic basins of the Atlantic and Pacific. The mean depth of the seafloor slopes gently downward toward the north. The basement topography, Figure 12, is formed by subparallel ridges 200 to 400 meters high and about $8 \mathrm{~km}$ apart. The ridges trend $285^{\circ}$ to $295^{\circ}$ and are remarkably continuous. The continuity of these ridges is clearly illustrated on the MCS profile (Fig. 13). The ridges produce strong trains of side echoes that merge with highs along the track. In the northern part of the area, sediments have filled the valley floors between ridges, which greatly attenuates the topographic relief.

In the southern part of the survey area, there is a steep-sided $v$-shaped valley. The rims of this valley form the highest and roughest topography in the region.

Sediments. The single-channel seismic reflection profiles show a transparent sedimentary layer that generally fills depressions in the basement topography. These deposits are not conformable with the basement, which suggests that a large proportion of the sediments have moved in laterally as bottom flows. This area is located at the distal end of the sedimentary apron over the western flank of the Palau-Kyushu Ridge. This apron was formed when the ridge was part of an emergent active volcanic arc (see the Site 448 Report; also, Karig, 1972), in the middle to late Oligocene. As a consequence, we would expect most of the sediments to be distal turbidites of this age range.

In some of the pockets beneath the transparent layer, a more opaque reflector that is nearly flat lying can be seen. These sediments may be the breccias that were drilled at Sites 290 and 447. An important feature to note is that there are no large volcanic structural features such as seamounts near the 447 drill site, so that it is unlikely that the basement is formed by postspreading volcanism.

Seismic-Refraction Studies. Two sonobuoy refraction measurements in the survey area, one by the Vema and the other by the Conrad, gave useful results. The Conrad profile $195 \mathrm{C} 20$ gave the better results, because the large air-gun source was used. Three refractors were observed (Table 1). The uppermost, with a velocity of $5.1 \mathrm{~km} / \mathrm{s}$, corresponds to Layer 2 . The layer is calculated to be $1.2 \mathrm{~km}$ thick. A velocity of $6.8 \mathrm{~km} / \mathrm{s}$ is measured in the underlying Layer 3, which is $2.7 \mathrm{~km}$ thick. The deepest refractor observed has a velocity of 7.6 $\mathrm{km} / \mathrm{s}$. This velocity is intermediate between Layer 3 and sub-Moho rocks; the value obtained may indicate a dipping Moho surface. 


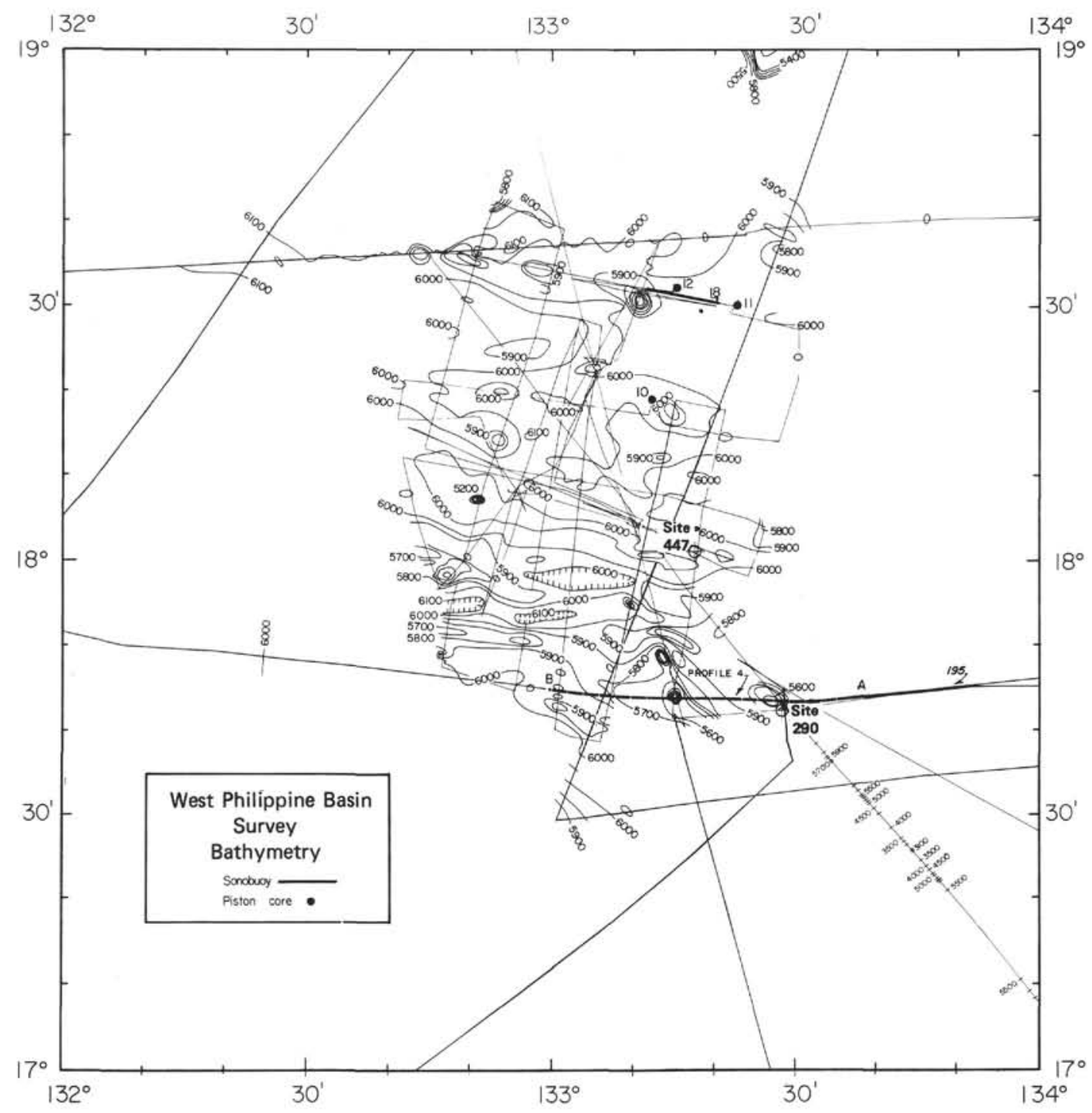

Figure 11. Bathymetric contour map of the survey area in the West Philippine Basin in the vicinity of DSDP Site 290 and IPOD-DSDP Site 447. (Contours are in corrected meters. Location of Profile 4 [Fig. 13] is shown by a heavy dashed line.)

The Vema profile $18 \mathrm{~V} 32$ revealed only one relatively strong refractor with a velocity of $7.0 \mathrm{~km} / \mathrm{s}$. This probably corresponds to Layer 3 . If a Layer- 2 velocity of 5.0 $\mathrm{km} / \mathrm{s}$ is assumed to be masked, the thickness of Layer 2 can be calculated as $1.3 \mathrm{~km}$.

Magnetics. Magnetic anomalies are well developed over most of the West Philippine Basin, and lineations can be traced with confidence in the area north and east of the Central Basin Ridge (Watts et al., 1977; Louden, 1976). This observation by itself is important, because it indicates that the trend of the spreading center at which the lithosphere of the West Philippine Basin was formed had to make a large angle with the paleofield declination. Figure 14 shows the magnetic anomalies within a $5^{\circ} \times 5^{\circ}$ area surrounding the survey site. Several of the prominent anomalies can be correlated between tracks (note the dashed lines) and are subparallel to the Central Basin Ridge. Within the survey region, a very prominent west-northwest lineation, associated with a sharp nega- tive anomaly (as viewed from the east in the figure), is revealed.

Correlating the anomaly sequence observed in the basin with the reversal chronology has proven difficult. Watts et al. (1977), for example, give two possible correlations for the sharp negative in the survey area:

1) it correlates with the older edge of Tertiary Anomaly 20 (about 50 m.y. old); or

2) it correlates with the younger edge of Mesozoic Anomaly M4 (about 116 m.y. old).

In neither case is the agreement convincing.

In major oceanic basins, a depth of 6000 meters is usually typical of the Mesozoic, whereas all of the drill results to date indicate a Tertiary age for the basement (Eocene to mid-Oligocene).

The problem of identifying the anomaly sequence makes it difficult to estimate the spreading rate. However, the estimates cited above suggest 4.0 to $4.5 \mathrm{~cm} / \mathrm{yr}$ as a half spreading rate. 


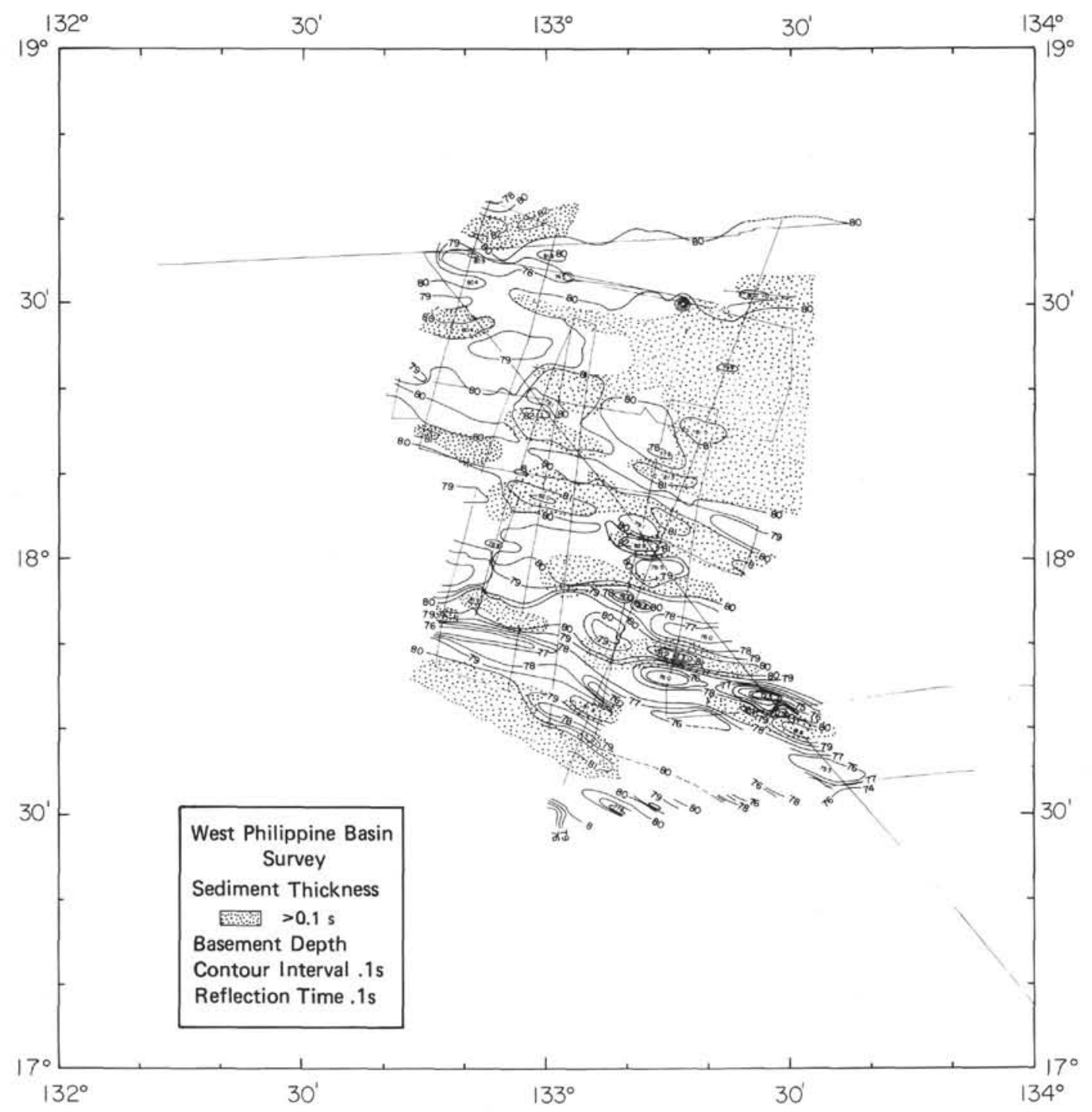

Figure 12. Contour map of the basement topography and the sediment distribution. (Sedimentary thicknesses are based on siesmic-reflection profiles.)

Geothermal Measurements. In the northeastern corner of the IPOD Site Survey area, where the sedimentary cover is relatively thick (about $200 \mathrm{~m}$ ) and pervasive, three measurements of the vertical temperature profile in the sediments were made (Fig. 15) using outrigged thermistor probes on a piston-coring device. Penetration of the deepest probe was just short of 6 meters in each case. However, the absolute depth below the seafloor shown in Figure 15C is poorly determined.

The remarkable feature is that widely different temperature profiles are obtained at stations so close together. This indicates that the geothermal heat-flow is being distorted near the surface, most probably by the lateral movement of pore waters in the oceanic crust beneath the sediments (Langseth and Herman, in press). All of the gradients (determined by points in the lower part of the profile) are less than theoretically expected over Tertiary oceanic crust (Fig. 15C). These predicted values for the gradient assume a typical thermal conduc- tivity for seafloor sediments of $0.84 \mathrm{Wm}^{-1} \mathrm{C}^{0-1}$. Station 5 yielded a gradient less than predicted over Mesozoic oceanic crust. The probable explanation for these lower-than-expected values is that significant amounts of geothermal heat are being carried out of the crust by water escaping through basement exposures. Note that Station 5, with the lowest gradient, is closest to a basement outcrop.

At Station 6, the gradient is not uniform with depth, rather it decreases downward. This effect has been observed elsewhere and has been associated with water movement through the sedimentary layer at rates of $10^{-8} \mathrm{~m} / \mathrm{s}$ or more (Anderson et al., 1979; Langseth and Herman, in press). Other possible causes of this curvature of the temperature profile, such as changing bottom-water temperature, seem very unlikely in this deep enclosed basin.

The importance of these results to drilling is that the pore waters at relatively low temperatures (a few to 


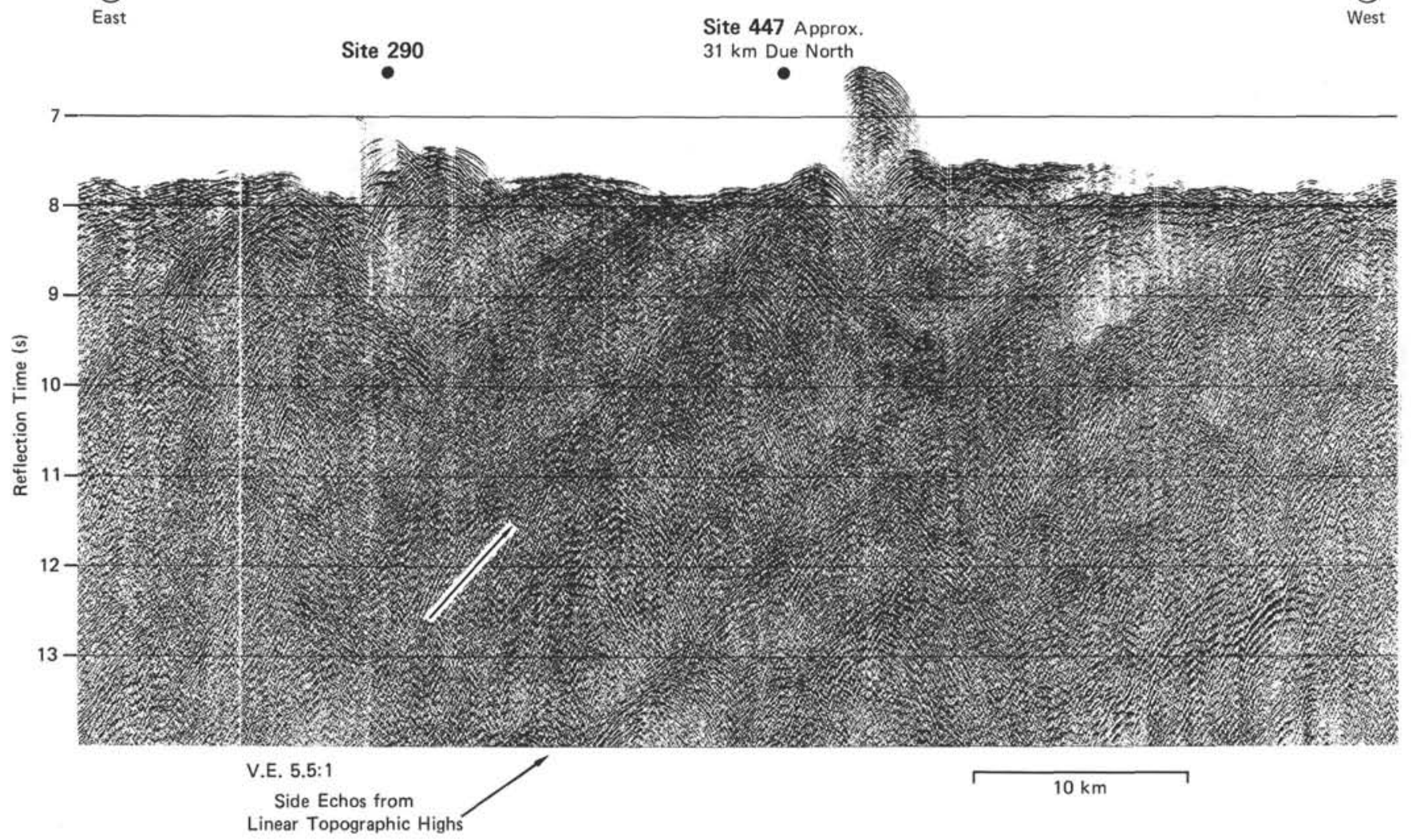

Figure 13. Profile 4: 24 -fold multichannel seismic profile across the IPOD-DSDP Site 447 survey area. (Note the side echoes from the linear topographic high trending at a small angle to the profile. The positions of DSDP Site 290 [Leg 31] and IPOD-DSDP Site 447 are indicated. See Fig. 11 for the location of the profile.)

$10^{\circ} \mathrm{C}$ above the bottom water) are flowing through the upper igneous crust at thermally significant rates (i.e., $10^{-8}$ to $10^{-9} \mathrm{~m} / \mathrm{s}$ ).

Summary. From the geophysical data of this survey and a large amount of earlier work, it is clear that the evolution and physiography of the West Philippine Basin is distinctly different from the basins of the eastern part of the Philippine Sea. Magnetic and topographic trends are west-northwest. The seafloor is deep and thinly sedimented. The crust beneath the basin is clearly oceanic, but the geophysical and geological evidence as to age of the lithosphere is ambiguous. The mode of its formation-whether it was part of a midoceanic ridge or formed behind a yet unidentified migrating arc, as was the Parece Vela Basin-cannot be determined from the present data. Samples from the basement provided by the Deep Sea Drilling Project may provide the best data for resolving these uncertainties.

\section{ACKNOWLEDGMENTS}

We gratefully acknowledge the help and support of the captains and crews of the Vema and Conrad; Dennis Hayes and Roger Anderson, the co-chief scientists on Conrad cruise 20-06; and Paul Stoffa, who directed the processing of the multichannel data. Dennis Hayes and John Bodine provided helpful reviews of the original manuscript. Annette Trefzer and Ana Maria Draganovic assisted with drafting and manuscript preparation.

The site-surveying work on the Vema was supported by National Science Foundation Grant UC/NSF C482-2. The multichannel transect and refraction work on the Conrad was supported by $\mathrm{Na}$ - tional Science Foundation grants UC/NSF C482-2 and OCE76-23382. Part of the analysis and interpretation was supported by National Science Foundation grants OCE75-16027, OCE78-17021, and OCE7620445. This paper is Lamont-Doherty Geological Observatory contribution No. 2930 .

\section{REFERENCES}

Anderson, R. N., 1975. Heat flow in the Mariana Marginal Basin. J. Geophys. Res., 80:4043-4048.

Anderson, R. N., Hobart, M. A., and Langseth, M. G., 1979. Geothermal convection through oceanic crust and sediments in the Indian Ocean. Science, 204:828-832.

Fischer, A. G., Heezen, B. C., et al., 1971. Init. Repts. DSDP, 6: Washington (U.S. Govt. Printing Office).

Heirtzler, J. R., Dickson, G. O., Herron, E. M., et al., 1968. Marine magnetic anomalies, geomagnetic field reversals, and motions of the ocean floor and continents. J. Geophys. Res., 73:21192136.

Karig, D. E., 1971a. Structural history of the Mariana Island Arc system. Geol. Soc. Am. Bull., 82:323-344.

1971b. Site surveys in the Mariana Area (Scan IV). In Fischer, A. G., Heezen, B. C., et al., Init. Repts. DSDP, 6: Washington (U.S. Govt. Printing Office) 681-689.

1972. Remnant arcs. Geol. Soc. Am. Bull., 83:1057-1068. 1975. Basin genesis in the Philippine Sea. In Karig, D. E., Ingle, J. C., Jr., et al., Init. Repts. DSDP, 31: Washington (U.S. Govt. Printing Office) $857-879$.

Karig, D. E., Anderson, R. N., and Bibee, L. D., 1978. Characteristics of back-arc spreading in the Mariana Trough. J. Geophys. Res., 83:1213-1226.

Karig, D. E., Ingle, J. C., Jr., et al., 1975. Init. Repts. DSDP, 31: Washington, (U.S. Govt. Printing Office).

Kroenke, L., and Scott, R., 1978. In the Philippine Sea-old questions answered-and new ones asked. Geotimes, 23:20-23. 


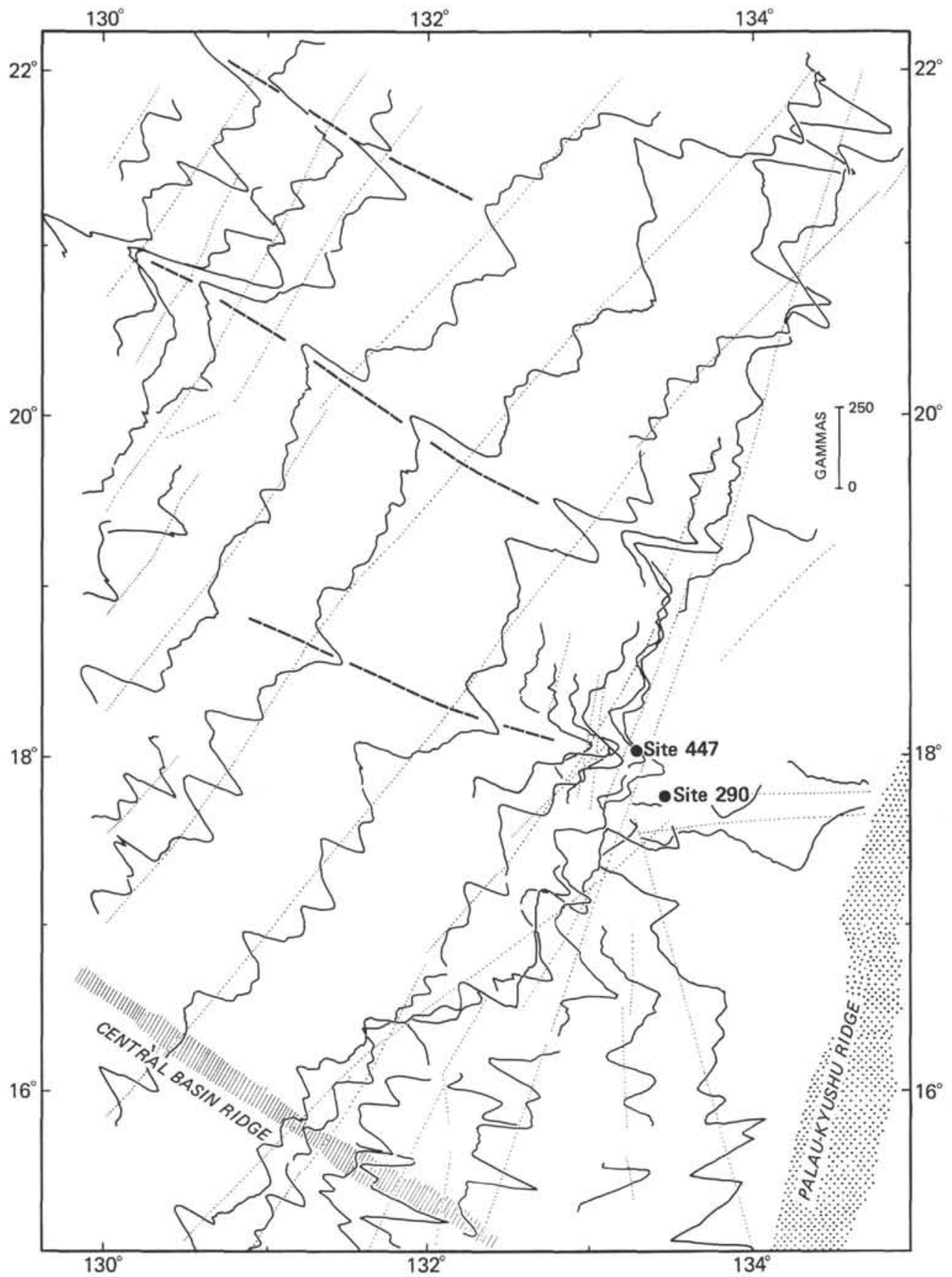

Figure 14. Magnetic anomalies plotted perpendicular to the ship tracks for the region surrounding IPOD-DSDP Site 447 and DSDP Site 290 (Leg 21). (Correlations from track to track of prominent anomalies are shown by dashed lines. The trend shown for the Central Basin Ridge is based on the gross topographic trends and does not indicate the trend of individual deeps, which is $280-285^{\circ}$ [Lewis and Hayes, in press].)

LaBrecque, J. L., Kent, D. V., and Cande, S. C., 1977. Revised magnetic polarity time scale for Late Cretaceous and Cenozoic time. Geology, 5:330-335.

Langseth, M. G., and Herman, B. M., in press. Heat transfer in the oceanic crust of the Brazil Basin. J. Geophys. Res.

La Traille, S. L., and Hussong, D. M., in press. Crustal structure across the Mariana Island Arc system. In Hayes, D. E. (Ed.), The Tectonic/Geologic Evolution of Southeast Asia: Am. Geophysical Union, Geophysical Monogr.

Lewis, S. D., and Hayes, D. E., in press. Structure and evolution of the Central Basin Fault, West Philippine Basin. In Hayes, D. E.
(Ed.), The Tectonic/Geologic Evolution of Southeast Asia, Am. Geophysical Union, Geophysical Monogr.

Louden, K. E., 1976. Magnetic anomalies in the West Philippine Basin. The Geophysics of the Pacific Ocean Basin and Its Margin: Am. Geophys. Union, Geophys. Monogr., 19:253-267.

Mammerickx, J., Fisher, R. L., Emmel, F. J., et al., 1977. Bathymetry of the East and Southeast Asian Seas. Geol. Soc. Am. Map Chart Series, MC-17.

Mrozowski, C. L., and Hayes, D. E., 1979. The evolution of the Parece Vela Basin Eastern Philippine Sea. Earth Planet. Sci. Lett., 46:49-67. 

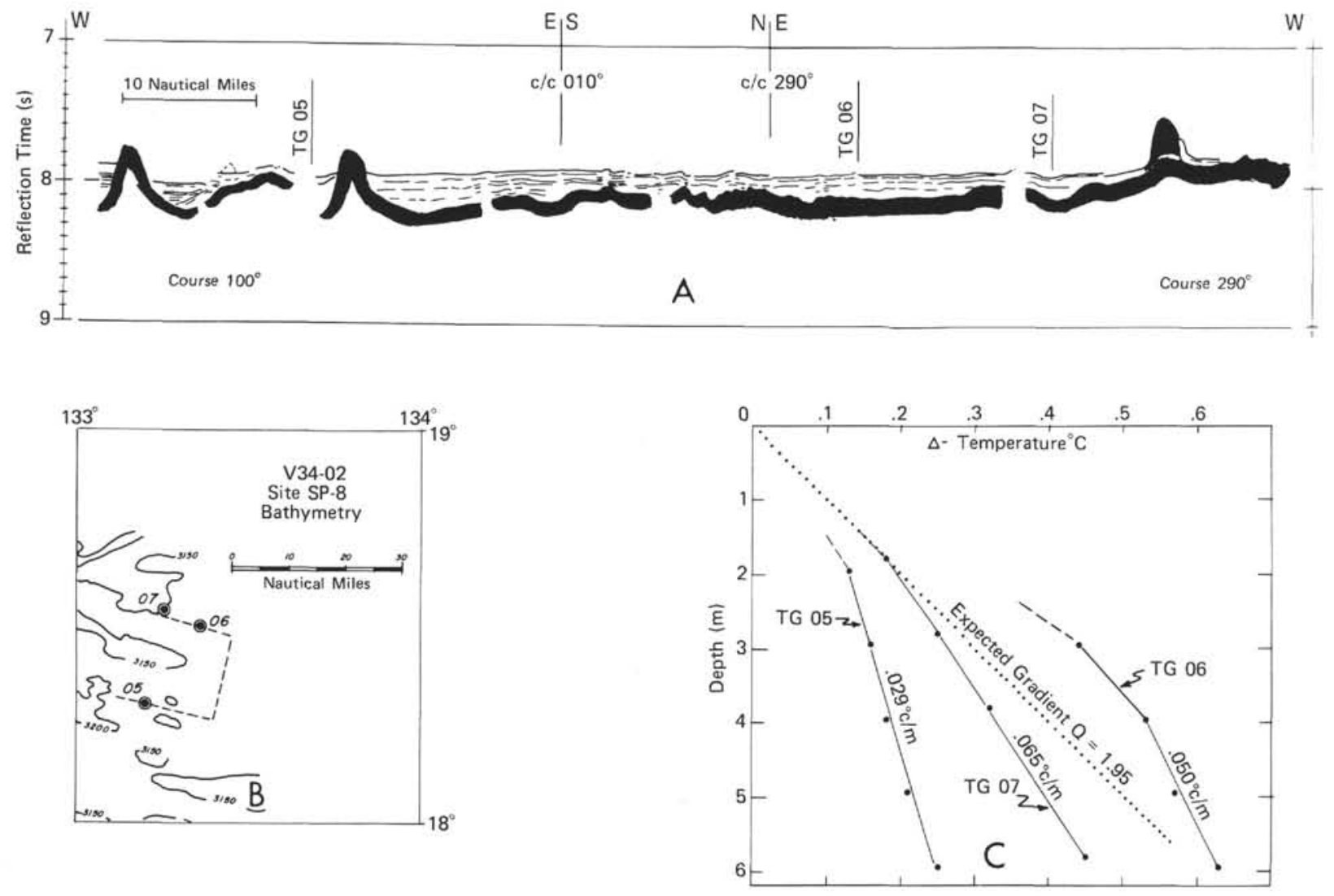

Figure 15. Geothermal observations in the West Philippine Basin survey area: A. a tracing of the seismic reflection record, with the locations of Stations TG 05, 06, and 07 indicated; B. an index map; and C. temperature profiles in the seafloor sediments measured at the three stations.

Murauchi, S., Den, N., Asano, S., et al., 1968. Crustal structure of the Philippine Sea. J. Geophys. Res., 73:3143-3171.

Parsons, B., and Sclater, J. G., 1977. An analysis of the variation of ocean-floor bathymetry and heat flow with age. J. Geophys. Res., 82:803-827.

Watts, A. B., Weissel, J. K., and Larson, R. L., 1977. Seafloor spreading in the marginal basins of the Western Pacific. Tectonophysics, 27:67-81.

\section{APPENDIX: IPOD TROUGH SURVEY}

After completion of the site survey for Hole 450, a short survey was attempted of a spectacular chasm (at approximately $18^{\circ} \mathrm{N}$, $139^{\circ} 20^{\prime} \mathrm{E}$ ) along the trend of the Parece Vela Rift. This chasm was first noted during the Conrad multichannel traverse of the Parece Vela Basin. The hole is a diamond-shaped depression whose longest dimension is about $40 \mathrm{~km}$. The four steep slopes that bound the feature strike northeast and northwest and do not parallel the main trends of the Parece Vela Rift. The floor of the deep is V-shaped and lies about 2500 meters below the surrounding seafloor and 7200 meters below sea level. We suggest the name IPOD Trough for this feature.

Dredging. We dredged the base of the slope in the northern end of the IPOD Trough and raised a suite of solid, fresh-looking blocks of basalt.
The basalt is dense and aphanitic and often has chilled rinds and clear alteration zones. There are thin manganese encrustations on the rocks.

More detailed petrographic descriptions were made of two samples (Daniel Fornari, personal communication):

$V 34$, D16-1-tholeiitic pillow basalt fragment. The sample is finegrained. The microcrystals consist of small, fine to fibrous laths of plagioclase (3\%); small subhedral augites (cpx) are scattered ships to the plagioclase laths (augites $=2 \%$ ); subhedral olivine microcrystals show some degree of corrosion by late-stage magmatic solutions $(2 \%)$; groundmass opaques $(2 \%)$ are uniformly distributed throughout the rock (serpentine [about $3 \%$ ]; groundmass $[88 \%])$.

$V$ 34, D16-2-subdoleritic diabase. The sample is very fresh coarse-grained rock that seems to have been an intrusive of some sort because of its crystallinity and mineral associations. A thin section shows large (up to $.5 \mathrm{~mm}$ ) laths of plagioclase $(40 \%)$, which enclose interstitial augite microcrystals $(35 \%)$ that are subhedral, and olivine microcrystals $(15 \%)$ that are also subhedral. Augite microcrysts are also found at the center of the large radiating plagioclase laths. Large opaques, both titanomagnetites and ilmenite, are abundant, the latter exhibiting some coarse trellis-type textures when it occurs as inclusions in large plagioclase lathe (opaques $=3 \%$; groundmass $=7 \%$ ). Some of the samples taken in this dredge may be datable by isotopic techniques. 